\title{
LEGISLATION OF 1972
}

Bantu Education Account Abolition Act, 20/1972

Bantu Laws Amendment Act, 23/1972

Bantu Transport Services Amendment Act, $111 / 1972$

$\begin{array}{lllllll}\text { Basters of Rehoboth Education Act, 85/1972 } & \ldots & \ldots & \ldots & \ldots & \ldots & 455 \\ \text { Coloured Persons in South West Africa Education Act, } & 63 / 1972 & \ldots & 455\end{array}$

Coloured Persons' Representative Council Amendment Act, 99/1972 ... 16

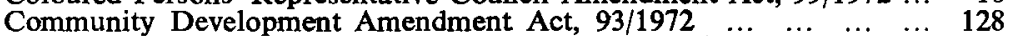

Contributions in Respect of Bantu Labour Act, $29 / 1972$

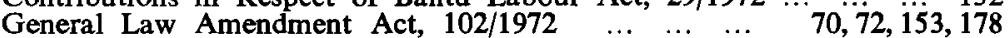

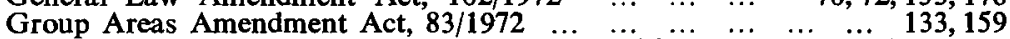

Mines, Works and Minerals in South West Africa Amendment Act, $\begin{array}{lllllllllllllll}47 / 1972 & \ldots & \ldots & \ldots & \ldots & \ldots & \ldots & \ldots & \ldots & \ldots & \ldots & \ldots & \ldots & \ldots & 454\end{array}$

Nama in South West Africa Education Act, $806 / 1972$

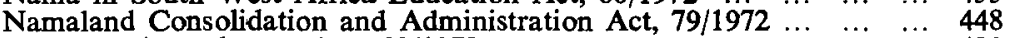

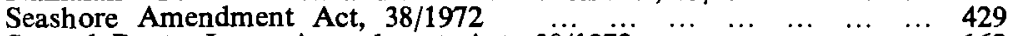

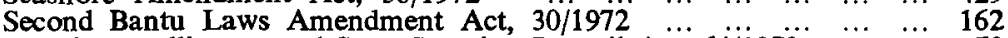

Security Intelligence and State Security Council Act, $6471972 \ldots \ldots$

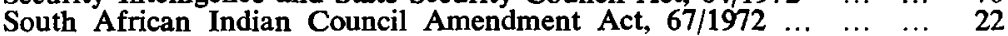

Suppression of Communism Amendment Act, $2 / 1972$.

Transport Services for Coloured Persons and Indians Act, $27 / 1972 \ldots .158$ 